\title{
Renal Cell Carcinoma Metastasizing To the Head and Neck: A Case Report and Literature Review
}

Ima-Abasi E. Bassey ${ }^{1}$, Edoise M. Isiwele ${ }^{2}$, Theophilus Ugbem ${ }^{1}$, Charles E. Anyanechi ${ }^{3}$, Sunday N. Okonkwo ${ }^{4}$ Akanimo Essiet $^{2}$

${ }^{\mathrm{T}}$ Department of Pathology, University of Calabar, Nigeria

${ }^{2}$ Department of Urology, University of Calabar Teaching Hospital, Nigeria

${ }^{3}$ Department of Oral and Maxillofacial Surgery, University of Calabar, Nigeria

${ }^{4}$ Department of Ophthalmology, University of Calabar Teaching Hospital, Nigeri

\section{Article History}

Received: 24.08.2020

Accepted: 09.09.2020

Published: 30.09 .2020

Journal homepage:

https://www.easpublisher.com/easjms

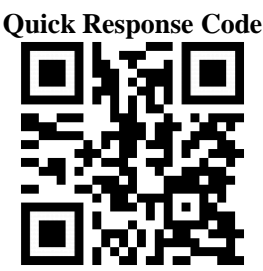

Abstract: Renal cell cancers are common and have a high rate of uncommon manifestations. A third of patients with renal cell carcinoma present first with features of metastasis. We report the case of a 43 year old woman presenting first to the ophthalmology clinic with a facial mass and to the urology clinic 2 months later. She thereafter had radical nephrectomy and subsequently, excision biopsy of the facial/ maxillary mass after initial evaluation. Histology of both specimen showed papillary renal cell cancer and clear cell papillary cancer, respectively. A consideration of renal cell cancer should be considered a strong differential when patients present with tumours of the head and neck, knowing that renal cancers can metastasize to virtually every part of the body.

Keywords: Renal cell cancers, Metastasis, Head and Neck, Maxillary, Nephrectomy, facial.

Copyright @ 2020: This is an open-access article distributed under the terms of the Creative Commons Attribution license which permits unrestricted use, distribution, and reproduction in any medium for non-commercial use (Noncommercial, or CC-BY-NC) provided the original author and source are credited.

\section{INTRODUCTION}

Renal cell carcinoma (RCC) is a common urological malignancy which accounts for $3 \%$ of all adult malignancies worldwide (Hafez, K. S. et al., 1999). In Calabar, South-Southern Nigeria it was found to account for $2.27 \%$ of adult urological malignancies in a study carried out in 2018 (Isiwele, E. M. et al., 2018). Renal cell carcinoma commonly metastasizes to the lungs, liver, bones and lymph nodes but less commonly to the head and neck region (Kelles, M. et al., 2012; \& Altunsoy, E. et al., 2019). It is the third most common infraclavicular neoplasm that metastasizes to the oral cavity, following that of lung and breast carcinoma (Pritchyk, K. M. et al., 2002).

In most cases, the primary tumor is discovered first but it has been noted that in one-third of cases, the first clinical manifestation is that of the metastatic tumor (Derakhshan, S. et al., 2018). We report a case of RCC with metastasis to the head and neck as first presentation.

\section{CaSe RePORT}

A 43 year old woman presented at the urology clinic of University of Calabar Teaching Hospital with left flank pain, not associated with haematuria or left flank swelling. She had presented 2 months earlier at the ophthalmology clinic of our facility with progressive periorbital mass over a 5 month period. There was no loss of vision or significant weight loss. Examination then had revealed a left periorbital soft tissue mass involving the mid cheek, about $8 \mathrm{~cm}$ by $7 \mathrm{~cm}$ in dimension with associated facial asymmetry. The mass was soft, non-tender, immobile, non- pulsatile, with no bruit. There was proptosis of the eye with medial displacement and restricted ocular movement in all directions. A diagnosis of left periorbital rhabdomyosarcoma with fibrous dysplasia as differential diagnosis was made and investigations requested with a plan for incisional biopsy. The patient did not follow through with the management and only presented 2 months later in the urology clinic. Abdominal examination on re-presentation revealed a left tender and ballotable kidney. Abdominopelvic ultrasound scans revealed an enlarged, lobulated left kidney with heterogenous parenchymal echogenicity and loss of cortico-medullary differentiation. There 
were multiple, well circumscribed heterogenous masses at the superior, inferior and mid-poles with cystic degeneration. There was no obvious para aortic lymphadenopathy. Intravenous urographic findings were those of an enlarged left kidney with upper and lower pole masses and non-excretion of contrast. There was associated distortion of the ipsilateral renal pelvis.
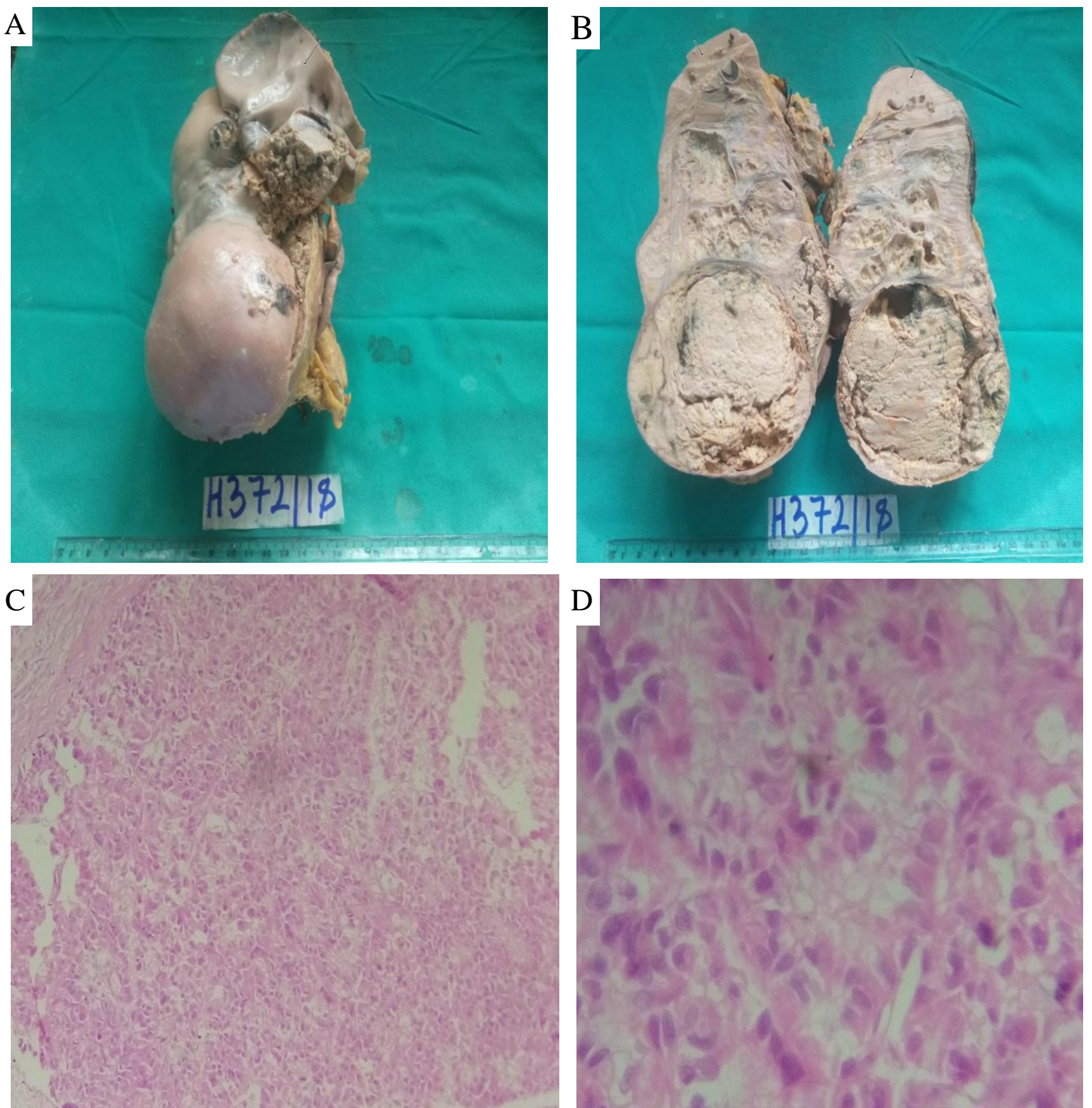

\section{D}

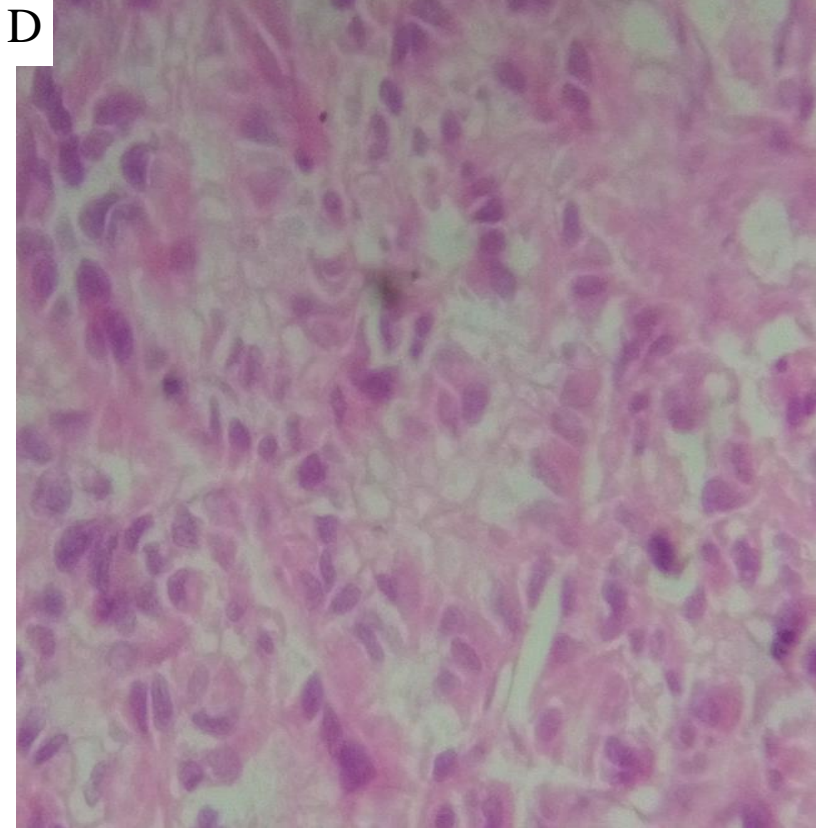

Figure 1: A- Gross Photograph of the kidney showing thickened capsule perforated by a greyish white tumour. B- Cut surface showing multi-lobulated greyish white tumor masses occupying the entire lower pole and greater part of the upper pole with residual renal tissues pushed toward the margins at the upper pole. C- Photomicrograph of the kidney showing papillae lined by single layer of cells with eosinophilic cytoplasm (H\&E x100). D- Photomicrograph showing papillae lined by single layer of cells with eosinophilic cytoplasm and pleomorphic nuclei having coarse chromatin patterns. Cells having clear cytoplasm also noted (H\&E x400). 


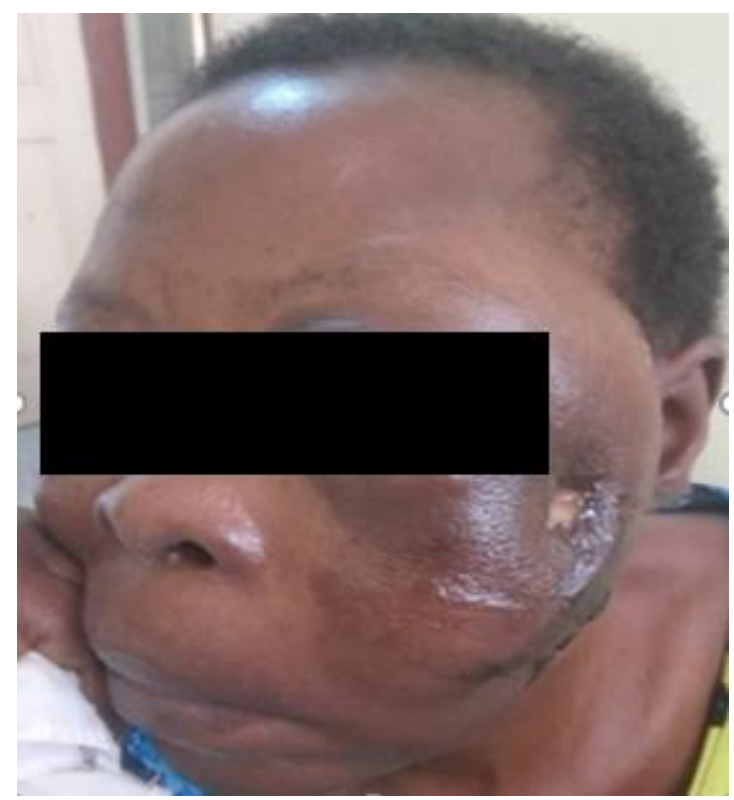

Figure 2: Photograph showing the mass on the left side of the patient's face and jaw.
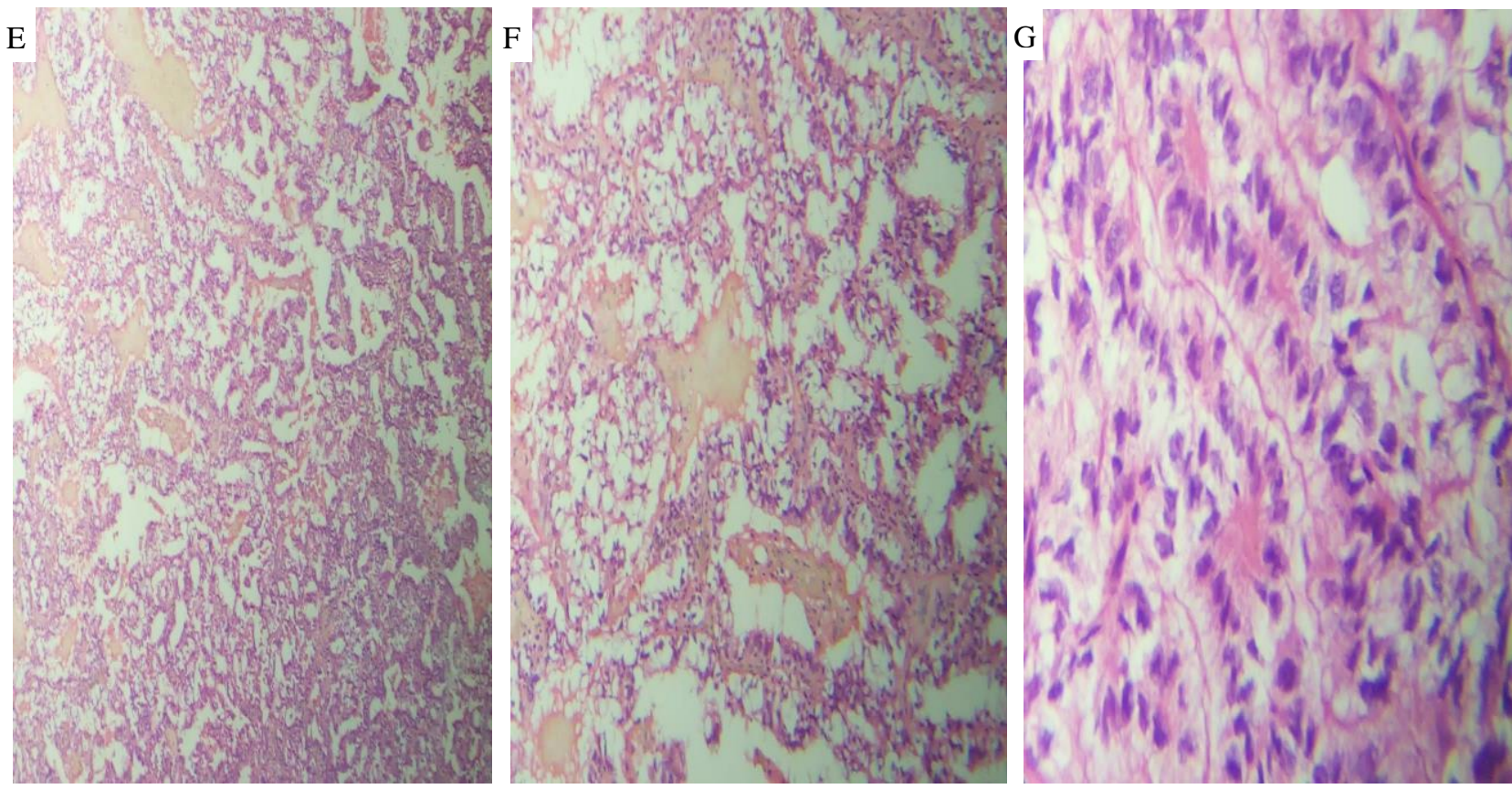

Figure 3: Histological sections of the maxillary tumour showing papillary fronds having fibro-vascular cores lined by neoplastic cells which vary from having scanty amphophilic cytoplasm with nuclei typically arranged in a single layer to having abundant eosinophilic cytoplasm. There is extensive clear cell change noted. (A: H\&E x40, B: H\&E x100, C: H\&E x400 magnification).

\section{DisCUSSION}

Renal cell carcinoma (RCC) has varied presentations resulting from paraneoplastic syndromes as well as uncommon metastasis (Ahmadnia, H. et al., 2013) often creating diagnostic dilemma. Hence it was once referred to in 1973 by Miyamoto and Helmus (Miyamoto, R., \& Helmus, C. 1973) as the malignancy with the most unusual and unpredictable behavior. It is noted to have very unusual metastasis like endobronchial, skeletal muscle, laryngeal, dermal and spermatic cord spread $^{7}$. Renal tumours can progress unnoticed to a large size in the retroperitoneum until metastatic disease appears, without symptoms of the primary disease. It can virtually metastasize to any location in the body. The classic triad of flank pain, flank mass and haematuria, occurs only in $10 \%$ of patients and often indicates advanced disease. Up to $40 \%$ of patients do not present with these symptoms. Approximately $30 \%$ of patients with renal carcinoma present with metastatic disease, $25 \%$ with locally advanced renal carcinoma, and $45 \%$ with localized disease (Cairns, P. 2011; Gibbons, R. et al., 1976; Golimbu, M. et al., 1986; \& Azam, F. et al., 2008). 
Less than $15 \%$ of RCC are noted to metastasize to the head and neck (Azam, F. et al., 2008). Surgery (radical nephrectomy) is the standard of care for localized RCC and involves removal of the kidney, the perinephric tissues including Gerota fascia and the ipsilateral adrenal gland (Azam, F. et al., 2008; \& Hartmann, J., \& Bokemeyer, C. 1999). The disease is both chemo- and radio-resistant, hence even in advanced cases, cytoreductive nephrectomy is indicated in improving the quality of life of the patient (Hartmann, J., \& Bokemeyer, C. 1999; \& Parashar, B. et al., 2014; Culp, S.H. 2015; Choi, R., \& Yu, J.B. 2019). Currently, newer agents targeting the vascular endothelial growth factor, such as bevacizumab and sorafenib, are undergoing trials and may improve the overall survival of patients with metastatic RCC (Ahmadnia, H. et al., 2013; \& Will, T.A. et al., 2008). It is advocated that once the primary tumor has been or can be excised, then metastatic lesions on the face/jaw should be resected ${ }^{7}$. The index case had excision biopsy of the facial and maxillary tumour 5 months after the radical left nephrectomy. It is documented that most patients die within one year after detection of head and neck metastasis and as such palliative therapies to improve quality of life should be the mainstay of the treatment considering the poor long-term prognosis (Ahmadnia, H. et al., 2013; \& Will, T.A. et al., 2008). The index case was lost to follow up about 13 months after initial diagnosis of head and neck metastasis and all attempts at reaching her have failed which may confirm the above earlier documented finding.

\section{CONCLUSION}

Consideration of metastasis from a renal malignancy should be high on the differential diagnosis list whenever there is a finding of head and neck malignancy due to the fact that RCC has a high rate of unusual metastasis. Examination and investigations to reveal the primary site must be instituted early. Also, when carrying out staging investigations for RCC with metastases, the head and neck region should also be examined. Surgery still remains the mainstay of treatment while clinical trials for targeted therapies are still ongoing

\section{REFERENCES}

1. Hafez, K. S., FERGANY, A. F., \& NOVICK, A. C. (1999). Nephron sparing surgery for localized renal cell carcinoma: impact of tumor size on patient survival, tumor recurrence and TNM staging. The Journal of urology, 162(6), 1930-1933.

2. Isiwele, E. M., Bassey, I. A. E., Ikpi, E. E., Enakirerhi, G. E., Otobo, F. O., Essiet, A., \& Ekwere, P. D. (2018). Histopathologic Patterns of Urological Malignancies in Calabar, SouthSouthern Nigeria: A Ten-Year Review. Journal of Cancer and Tumor International, 1-10.
3. Kelles, M., Akarcay, M., \& Kizila,y P.A. (2012). Metastatic Renal Cell Carcinoma. J Craniofac Surg., 3(4), 302-303.

4. Altunsoy, E., Özeç, I., \& Gültekin, E. Y. (2019). Metastasis of Renal Cell Carcinoma to Mandible. Journal of Case Reports, 9(1), 4043.

5. Pritchyk, K. M., Schiff, B. A., Newkirk, K. A., Krowiak, E., \& Deeb, Z. E. (2002). Metastatic renal cell carcinoma to the head and neck. The Laryngoscope, 112(9), 1598-1602.

6. Derakhshan, S., Rahrotaban, S., Mahdavi, N., \& Mirjalili, F. (2018). Metastatic renal cell carcinoma presenting as maxillary lesion: Report of two rare cases. Journal of oral and maxillofacial pathology: JOMFP, 22(Suppl 1), S39.

7. Ahmadnia, H., Amirmajdi, N. M., \& Mansourian, E. (2013). Renal cell carcinoma presenting as mandibular metastasis. Saudi Journal of Kidney Diseases and Transplantation, 24(4), 789-92.

8. Miyamoto, R., \& Helmus, C. (1973). Hypernephroma metastatic to the head and neck. Laryngoscope, 83:898-905.

9. Cairns, P. (2011). Renal cell carcinoma. Cancer Biomark, 9(1-6):461-73.

10. Gibbons, R., Montie, J., Correa, R.J., \& Mason, J. (1976). Manifestations of renal cell carcinoma. Urology, 8(3), 201-206.

11. Golimbu, M., Tessler, A., Joshi, P., Al-Askari, S., Sperber, A., \& Morales, P. (1986). Renal cell carcinoma: survival and prognostic factors. Urology, 27(4), 291-301.

12. Azam, F., Abubakerr, M., \& Gollins, S. (2008). Tongue metastasis as an initial presentation of renal cell carcinoma: a case report and literature review. Journal of Medical Case Reports, 2(1), 249.

13. Hartmann, J., \& Bokemeyer, C. (1999). Chemotherapy for renal cell carcinoma. Anticancer Res., 19(2C), 1541-1543.

14. Parashar, B., Patro, K. C., Smith, M., Arora, S., Nori, D., \& Wernicke, A. G. (2014, March). Role of radiation therapy for renal tumors. In Seminars in interventional radiology (Vol. 31, No. 1, p. 86). Thieme Medical Publishers.

15. Culp, S.H. (2015). Cytoreductive nephrectomy and its role in the present-day period of targeted therapy. Ther Adv Urol., 7(5), 275285.

16. Choi, R., \& Yu, J.B. (2019). Radiation Therapy for Renal Cell Carcinoma. Kidney Cancer, 3:1-6.

17. Will, T.A., Agarwal, N., \& Petruzzelli, G.J. (2008). Journal of Medical Case Reports Oral cavity metastasis of renal cell carcinoma: A case report. J Med Case Rep., 2, 313. 